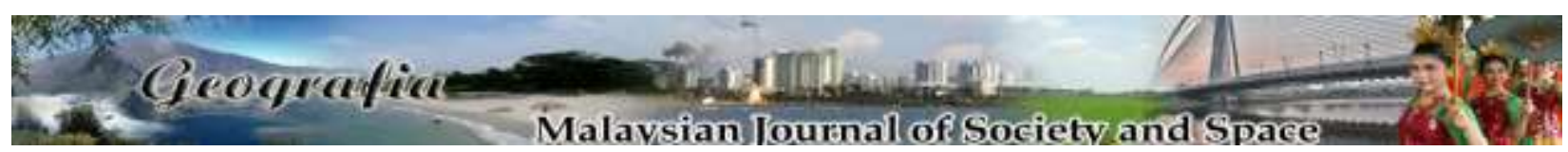

\title{
Relationships between basin area and sediment yield upstream Shiroro reservoir, north-central Nigeria.
}

\author{
Daramola Japheth, Lam Kuok Choy, Mohd. Ekhwan Toriman, Mokhtar Jaafar \\ Geography Programme, \\ Center for Research in Development, Social \& Environment (SEEDS), \\ Faculty of Social Sciences and Humanities, Universiti Kebangsaan Malaysia. \\ Correspondence: Lam Kuok Choy (lam@ukm.edu.my)
}

Received: 26 June 2019; Accepted: 21 July 2019; Published: 28 August 2020

\begin{abstract}
Sediment yield and basin area relationship in a watershed is a very crucial factor in Best Management Practices (BMPs) and reservoir sustainability. Therefore, the study was conducted to examines the suspended sediment concentration (SSC) of the four sub-watersheds of Kaduna watershed north-central Nigeria to aid the dam sustainability and BMP within the watershed. Water samples were collected bimonthly for 8 months (March-October 2018) and subjected to laboratory analysis for SSC and turbidity measurements. With the aid of ArcSwat2012, the watershed was delineated into four sub-watersheds, soil and land-use were classified for a proper understanding of the watershed. The findings demonstrated an inverse relationship between the size of the sub-watersheds and SSC. The smallest Dinya sub-watershed (1\%) contributes approximately $25 \%(3781.5 \mathrm{mg} / \mathrm{l})$ of the SSC while the largest Kaduna (80\%) contributes approximately 26\% (3889mg/l), Sarkinpawa (11\%) and Gutalu (8\%) contributes approximately $26 \%(3844 \mathrm{mg} / \mathrm{l})$ and $23 \%(3444 \mathrm{mg} / \mathrm{l})$ of SSC respectively. The highest average turbidity was recorded in Sarkinpawa sub-watershed, followed by Dinya, Gutalu, and Kaduna. The SSC and turbidity results followed the rainfall pattern while the regression results for the four subwatersheds shows a good level of linearity between SSC, rainfall and turbidity, Therefore, it is recommended that sediment management practice is to be carried out along sub-watersheds Dinya and Sarkinpawa and Gutalu to reduce the high rate of sediment influx into the reservoir from these smaller sub-watersheds. Also, detail study of the smaller sub-watersheds is highly recommended for a better understanding of the factors responsible for high sediment generation in these sub-watersheds.
\end{abstract}

Keywords: basin area, best management practice, Kaduna watershed, suspended sediment concentration (SSC), Shiroro reservoir, relationship. 
GEOGRAFIA Online ${ }^{\mathrm{TM}}$ Malaysian Journal of Society and Space 16 issue 3 (26-44)

(C) 2020, e-ISSN 2682-7727 https://doi.org/10.17576/geo-2020-1603-03

\section{Introduction}

Watershed management intervention is a process of curbing soil erosion and sediment yield through the introduction of Best Management Practices (BPMs) (Adeogun et al., 2018). Therefore, a good understanding of the relationship between basin area and sediment yield is very important, because it gives considerable information about erosion prone area that will guide the authority concern in the development of Best Management Practices that will reduce sediment yield generation within the watershed. Studies have established a relationship between the basin area and sediment load generation in a watershed. Basin area is the total geographical extent or area drained by a river and its tributaries. While sediment yield, according to Morris and Fan (1998), is the volume of sediments exported by a basin over a time period, which is also the amount that will enter a reservoir located downstream limit of the basin.

Studies have shown that basin area is one of the physical factors that control the amount of suspended sediment yield (Summerfield \& Hilton, 1994; Williams, 1975; Walling, 1994; Toriman et. al., 2009). Literatures has revealed both positive and negative relationship between sediment yield and basin area. Positive relationship if the sediment yield increases as basin area increases (Karaushev, 1977; Owens \& Slaymaker, 1992) and negative (inverse) relationship if the sediment yield decreases with increase basin area (Schumm, 1977; Karaushev, 1977). Over the years the inverse relationship has become the generally accepted norms as far as basin area and sediment yield relationship is concerned (Milliman \& Syvitski, 1992; Dedkov, 2004; Birkinshaw \& Bathurst, 2006). Some of the reasons advanced for these submissions is that increase in basin size led to decrease in transporting energy giving room to increase deposition in channel bars and valley floors, because of the increase in hillslope sediment source distance and the channel, making erosion of less spatial consequence (Dedkoy, 2004).

However, it was established that basin area relationship with sediment is best defined in a region similar in land use, runoff and geology in order to get a good result (Morris \& Fan, 1997; Dunne \& Leopold, 1978; Birkinshaw \& Bathurst, 2006). Milliman \& Syvitski (1992) confirmed that the topography and basin area have a dominant influence on sediment yield. As sediment yield becomes transport limited due to topographical complexity that associated with drainage basin increase. This inverse relationship was corroborated by Dedkov (2004) that total suspended sediment yield increases downstream, but not as fast as the basin area increases, therefore, specific suspended sediment yield decreases as basin area increases. Birkinshaw \& Bathurst (2006) reported both direct and inverse relationships based on the principal source of sediment in transport like Dedkov (2004). Ichim (1990), also confirmed inverse relationship in small basins and attributed it to relief, higher precipitation and higher erodible rock as a factor that can lead to high sediment delivery ration.

However, a positive relationship has been observed in some rivers by Karaushev (1977); Owens \& Slaymaker (1992) between specific sediment yield and drainage basin area, these are usually considered to be a deviation from the general prevailing trend. Authors like Milliman \& Syvitski (1992), Romero Díaz et. al., (1992), and Wasson (1994), have identified that a relationship exists between sediment yield and the drainage basin area, in the sense that the more extensive the surface area to be drained the greater the yield. Therefore, the major aim of this study is to ascertain the type of relationship that exists between the four sub-watersheds that supply water to Shiroro reservoir and sediment yield in Kaduna watershed. The objectives seek to determine the average monthly suspended sediment concentration (SSC) and turbidity of the four sub-watersheds reaches that constitutes Kaduna watershed and identify the sub-watershed 
that requires urgent BMP for the Shiroro dam sustainability.

\section{Method and Study Area}

The material used for this study includes $30 \mathrm{~m}$ resolution DEM of the study area acquired from Shuttle Rader Topography Mission (SRTM). The land use and the land cover map was extracted from West Africa: Land Use and Land Cover Dynamics 2013 produced by U.S. Geological Survey Earth Resources Observation and Science (USGS EROS), and Soil map of Nigeria (soil types and texture), from FAO Soil database 2009, of $1 \mathrm{~km}$ resolution and the sites selection for water sample collections was based on Singhal et al., (1981) recommendations. The reconnaissance team after careful consideration and deliberation identified and selected four sites within the watershed area that nearly met specified sampling criteria (Table 1).

Table 1. Geographic location of sample points in each sub-watershed

\begin{tabular}{ccccc}
\hline S/n & Sample points & Sub-watershed & Latitude & Longitude \\
\hline 1. & Reach Kaduna & Kaduna & 10.100509 & 6.883008 \\
2. & Reach Sarkinpawa & Sarkinpawa & 10.062851 & 6.93419 \\
3. & Reach Gutalu & Gutalu & 9.902773 & 6.883824 \\
4. & Reach Dinya & Dinya & 9.893015 & 6.853076 \\
\hline
\end{tabular}

SWAT model divided the watershed into basins using the DEM, subsequently, the basins were divided into several Hydrologic Response Unit (HRU) using the land-use, soil and slope. Kaduna watershed was divided into four sub-watersheds (Kaduna, Sarkinpawa, Gutalu and Dinya) based on the ArcSWAT model stream network delineation. The soil, land use and land cover data obtained were reclassified into five (5) and eight (8) classes respectively to suit SWAT model format. The soil data were complemented by additional information of twenty (20) soil samples collected from two different layers $(0-30 \mathrm{~cm}$ and $30-100 \mathrm{~cm})$ within the study area watershed and analyzed in a soil laboratory. The study area slope was classified into two levels slope using the multiple slope option, the first class with a lower limit of 0 and an upper limit of 5 while the second class has a lower limit of 5 and upper limit of 9999.

Suspended sediment sampler used in this study was the USDH-2A sampler (Figure 1A), a version of depth-integrating sampler that traverses the complete depth of the stream and back at a uniform rate (USDH-2A 2013). Figure 1B shows the sampler assemblage. The sampler was lowered from the surface to the bottom of the stream and returned to the surface at an almost same constant rate to ensure that the sampler did not hit the bottom of the stream to avoid bed disturbance that might introduce sediment into the nozzle thereby altering the concentration of the sample (Figure 1C). 

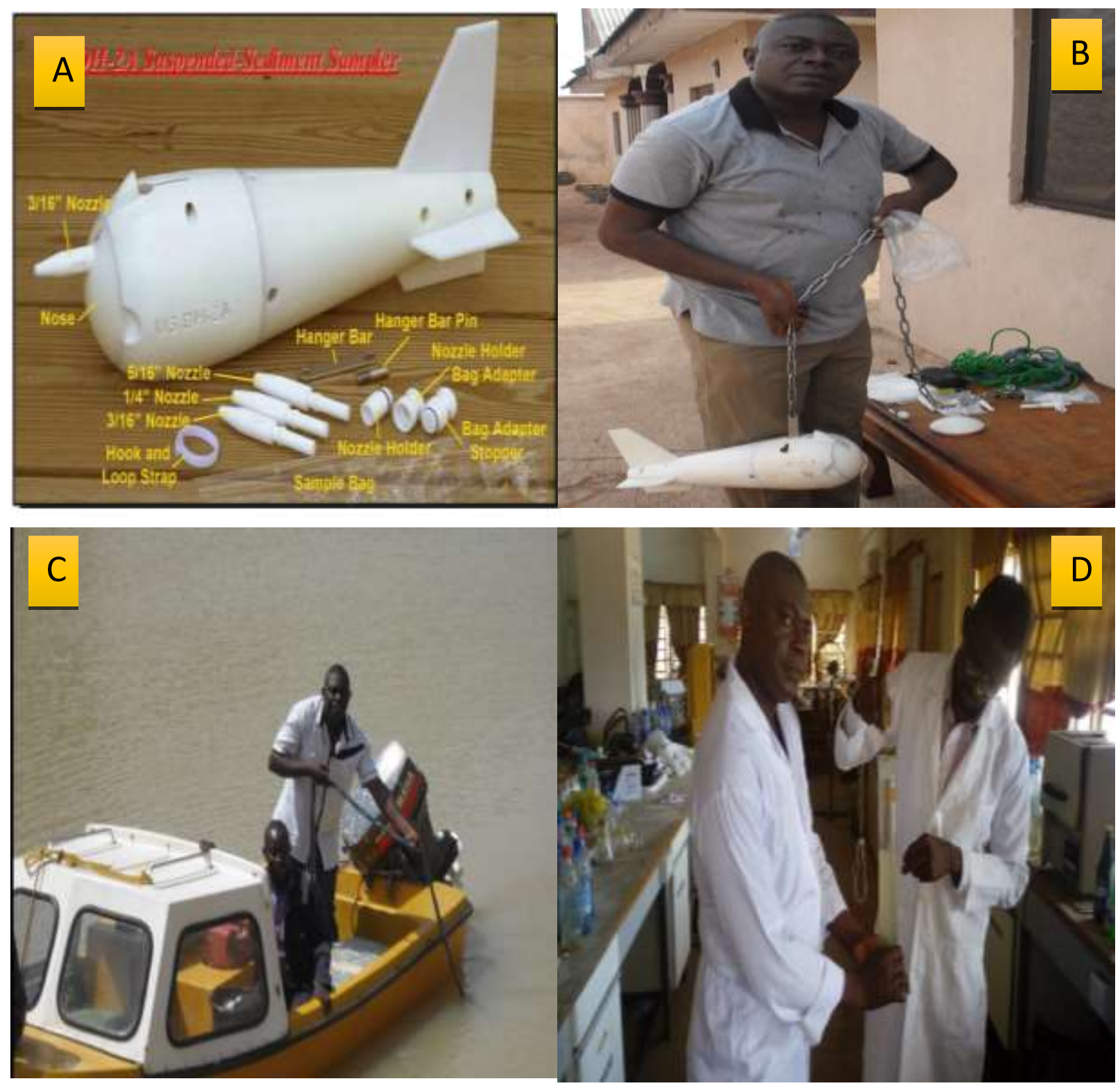

Figure 1. A) US-DH-2A sampler, B) US-DH-2A sampler assemblage, C) Water samples collections at sampling points, D) Laboratory analysis of SSC and Turbidity.

Sediment sampling was done twice in a month starting from March 2018 to September 2018. Upon collection of the samples, it was poured in a clean container and labelled appropriately and transported to the laboratory for analysis (Figure 1D). The suspended sediment concentration in the water samples was determined in the laboratory using Bartram \& Balance (1996) and APHA (1992) described methods. A known volume (100ml) of raw water was filtered through a pre-weighed $0.45 \mu \mathrm{m}$ pore diameter filter paper. Water samples were filtered through the filtering apparatus and the resulting residue in the filter papers were dried at room temperature. The Total Suspended Solid (TSS) was then calculated in $\mathrm{mg} / \mathrm{l}$ using the following equation: 


$$
\mathrm{TSS}=\frac{(A-B)}{\text { vol of sample }(\mathrm{ml})}: 1000
$$

Turbidity measurement of the samples was carried out using the Secchi Disc method (Zhen-Gang, 2017). There is a weight centrally placed to facilitates the sinking of the disc, the disc was lowered in the water and the depth $(\mathrm{cm})$ at which it disappeared was noted, the disc was then slowly raised and the depth at which it reappears was also noted. Thus, the calculation is as follows:

$$
\text { Secchi disc transparency }(\mathrm{cm})=\frac{A+B}{2}
$$

Where, $\mathrm{A}=$ depth at which disc disappears $(\mathrm{cm})$; and $\mathrm{B}=$ depth at which Secchi dis reappears (cm).

The study area, Kaduna watershed is located in north central Nigeria, West Africa geographically is located between latitude $9.35^{\circ} \mathrm{N}$ and $11.28^{\circ} \mathrm{N}$ and Longitude $6.45^{\circ} \mathrm{E}$ and $8.55^{\circ} \mathrm{E}$ with an estimated land area of $32,124.63 \mathrm{~km}^{2}$. The elevation range of the watershed is between $377 \mathrm{~m}$ to $1544 \mathrm{~m}$ and mean elevation of $683 \mathrm{~m}$ above sea level. The four major rivers are Kaduna $(550 \mathrm{~km})$ Sarkinpawa $(88.6 \mathrm{~km})$, Gutalu $(104.3 \mathrm{~km})$ and Dinya $(16.7 \mathrm{~km})$ in length, these rivers and their tributaries traverse the study area watershed (Figure 1).
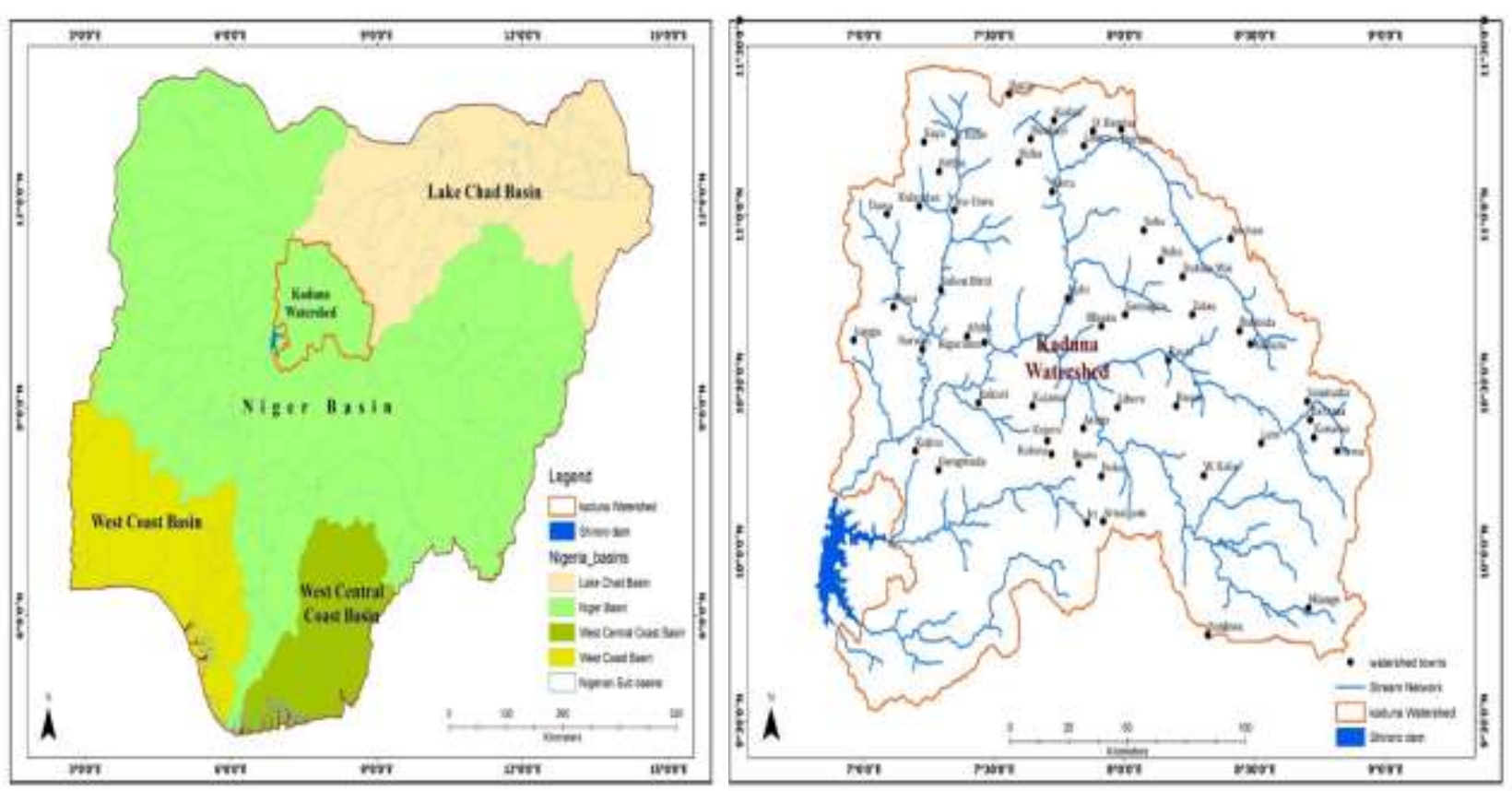

Source: Author's Field work and analysis (2019).

Figure 1. Map of Nigeria Showing Kaduna Watershed 
The region experiences a single maximum of rainfall that lasts for about six months, from April to September followed by a dry season (Areola et al., 2014). However, based on the available records sometime the rainfall duration is about eight to ten months (March to October) (Mohammed 2014). Rainfall in March is mostly less than $20 \mathrm{~mm}$ and October less than $100 \mathrm{~mm}$. The mean annual rainfall declines from $1200 \mathrm{~mm}$ in the south to about $1000 \mathrm{~mm}$ in the north, the northern part of the watershed is a little drier than the south (Areola et al., 2014). The rainfall pattern in the study area exhibits the monsoon characteristics movement, the seasonal wind shift produced by thermodynamic contrast between the Atlantic Ocean and the land (Bello et al., 2012). The Saharan heat low and southwesterly wind bring moisture inform of rainfall to the continent (Thorncroft et al., 2011; Peyrillé \& Redelsperger, 2007).

The watershed vegetation is mostly guinea savannah which is mainly characterized by tall grasses and scattered trees. The vegetation follows the rainfall pattern of the watershed. The economic activities of the people living within the watershed are farming, fishing, hunting, trading and weaving. Majority of the people in the area are farmers and their concentration are mainly on subsistence farming. The study area geology consists of basement complex also known as pre-Cambrian rocks (Figure 2) formed over 1,500 million years ago and regarded as the oldest and most stable rock in Nigeria (Areola et al., 2014). The soil in the study area is predominantly sandy loam soil which constitutes about $41.94 \%$ of the total soil.

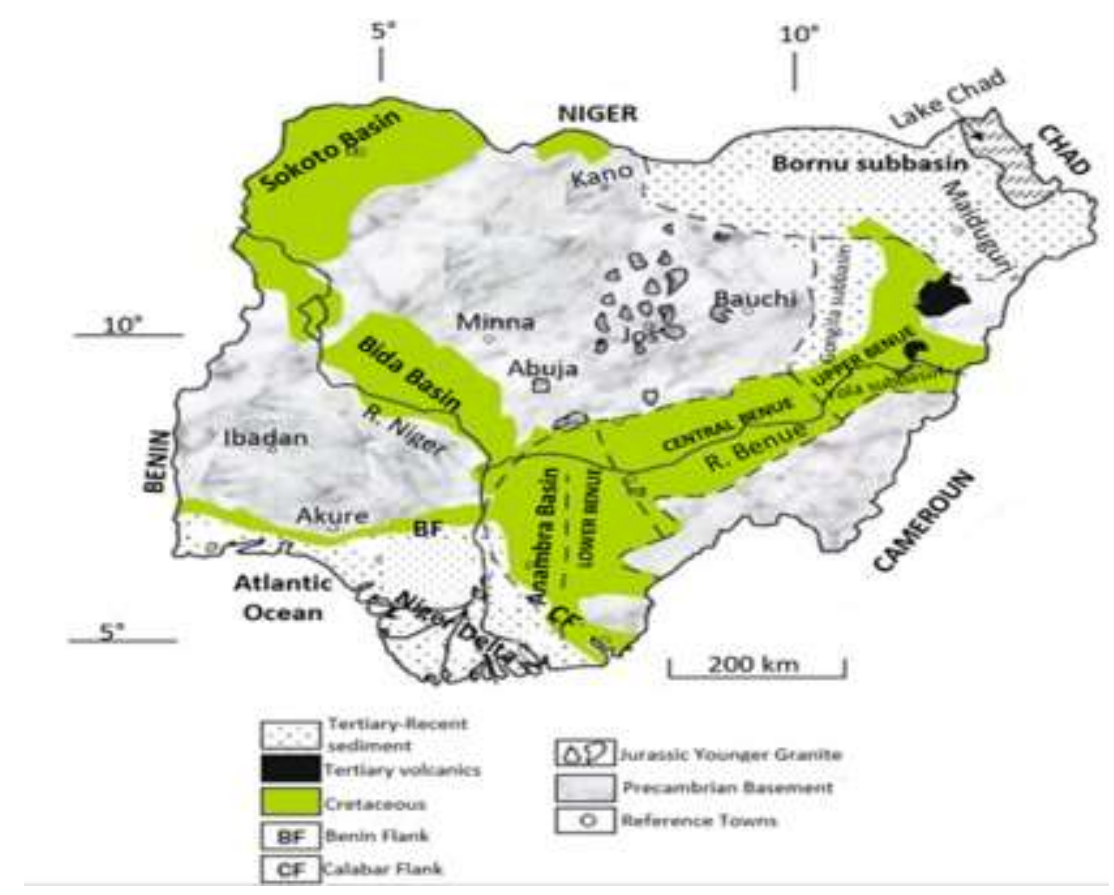

Source: Igwe \& Adepehin (2013).

Figure 2. Geological Map of Nigeria.

\section{Results and Discussion}

In this study data analysis can be categorized into two i.e. laboratory analysis of the water samples and SWAT model analysis of watershed delineation, land-use and soil classifications. 
This corroborates Toriman (2012) that the combination of data and modeling analyses can be used to evaluate sediment characteristics for short and long-term periods.

\section{ARCSWAT sub-watersheds delineation}

Kaduna watershed was divided into four sub-watersheds based on the ArcSWAT model stream network delineation (Figure 3A \& B). These comprise of the Kaduna river and its stream network with 67 basins and the largest sub-watershed with $80 \%$ total land area, followed by Sarkinpawa river and its stream network, it comprises of 7 basins and $11 \%$ total land area, Gutalu river and its stream network comprise of 7 basins with $8 \%$ per cent of total land area and Dinya river and its stream network comprises of only 1 basin and constitutes $1 \%$ of the total land area.
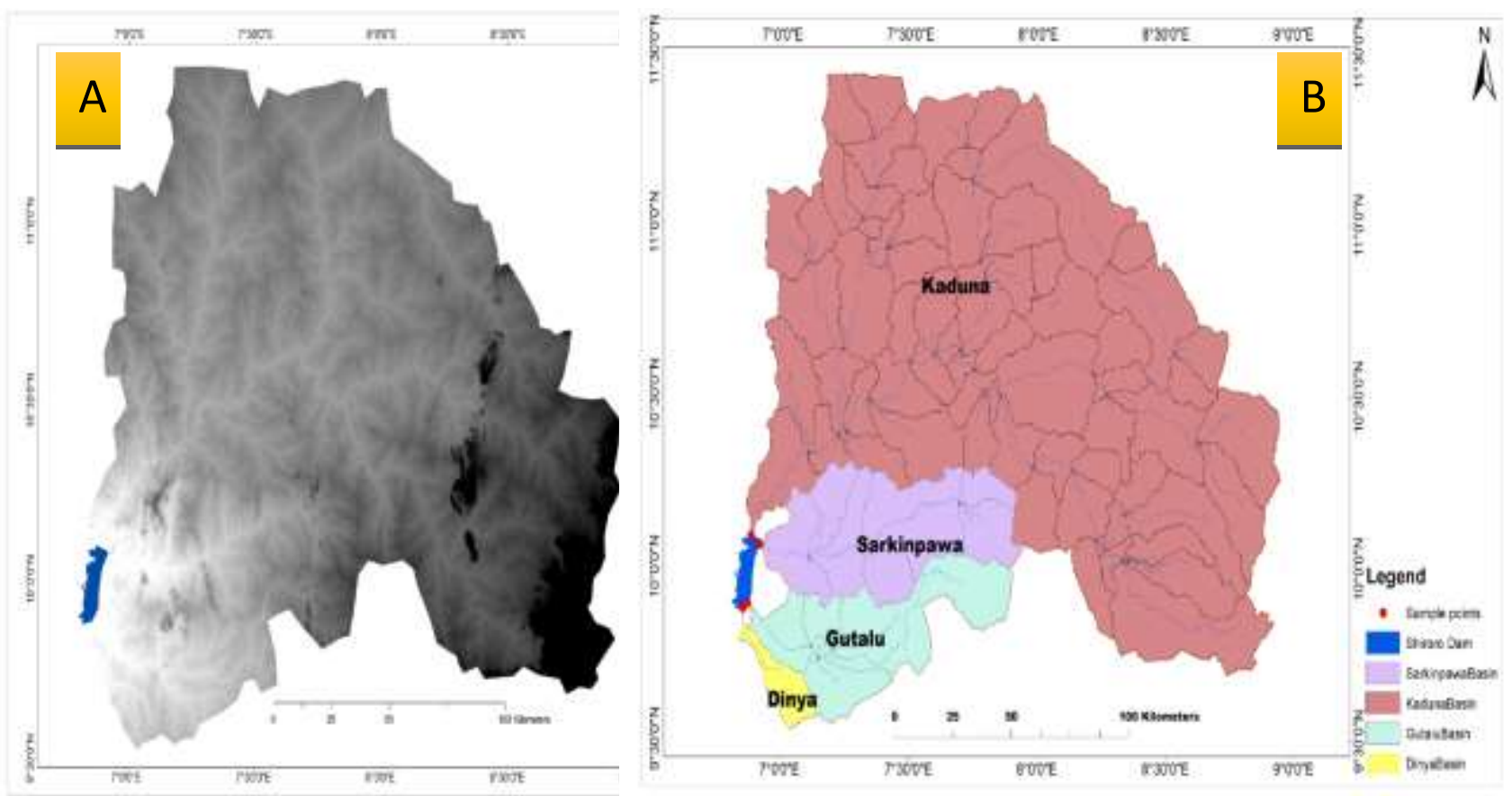

Source: Author's Analysis and Compilation (2019).

Figure 3. A: Kaduna Watershed DEM. B: Sub-watersheds Delineation and Stream network

The analysis revealed Kaduna sub-watershed to be the biggest among the four subwatersheds with $25,674.65 \mathrm{~km}^{2}$ land area followed by Sarkinpawa $\left(3,412.96 \mathrm{~km}^{2}\right)$, Gutalu $\left(2,671.79 \mathrm{~km}^{2}\right)$ and Dinya $\left(365.22 \mathrm{~km}^{2}\right)$ respectively. Ordinarily, Kaduna sub-watershed been the biggest would have been expected to have the highest sediment yield contribution to the reservoir (Milliman and Syvitski 1992; Romero Díaz et al. 1992; Wasson 1994). But the result in (Table 3.4) revealed otherwise, indicating reverse relationships between basin area and sediment yield in Kaduna watershed. The SSC decrease with increase basin land area corroborating Griffiths et al., (2006) and Oyebande, (1981).

\section{Land use and Land Cover (LULC), Soil and Slope Classification}

The study area watershed land-use land cover map was reclassified by the SWAT model into 
eight (8) land-use classes from the initial twenty-five (25) classes as shown in Figure 4A.

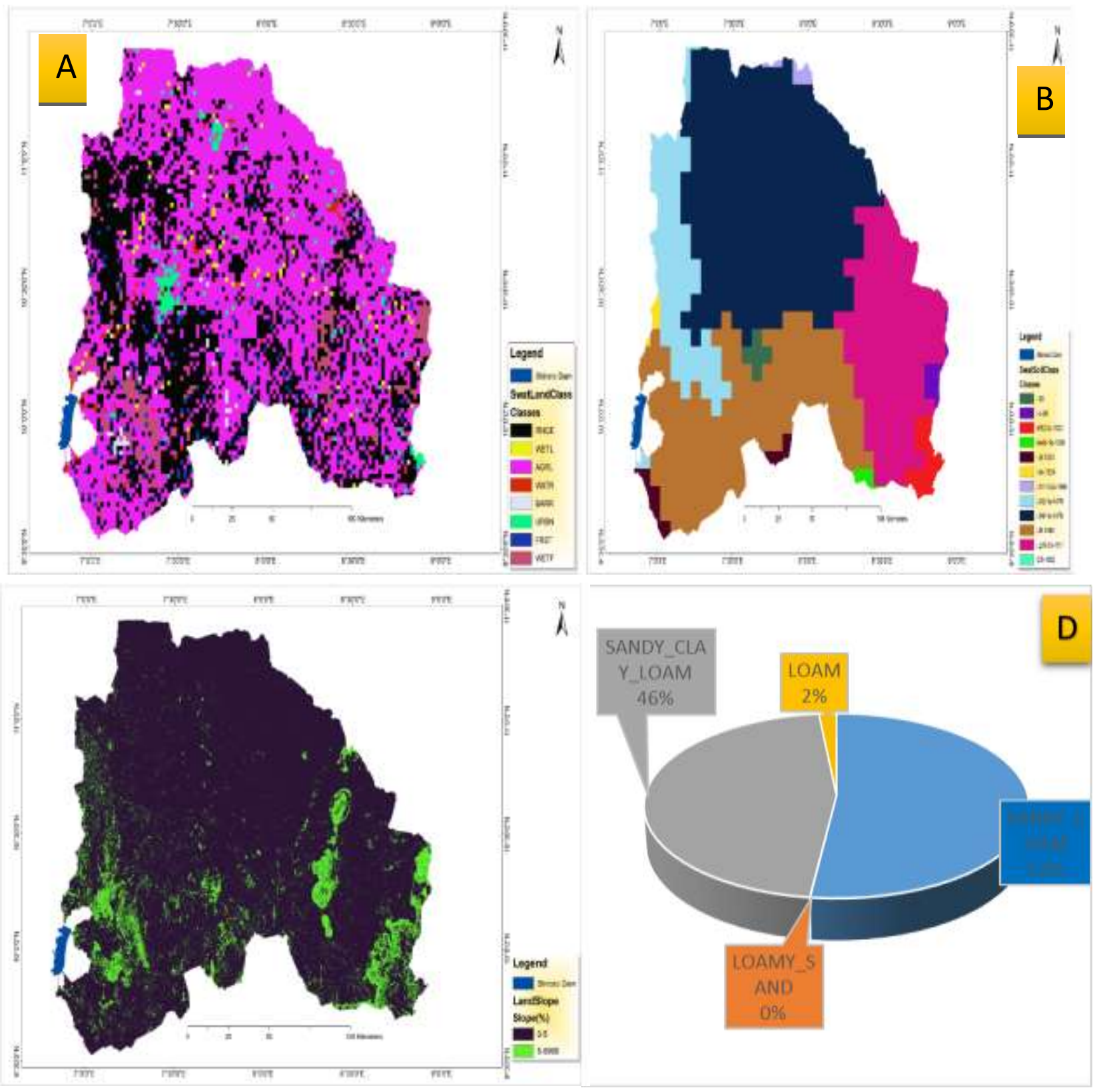

Source: Author's Analysis and Compilation (2019).

Figure 4. Kaduna Watershed, A) Land-use and Land Cover, B) Soil Classification, C) Slope Classification and, D) $\%$ Soil watershed classification

Table 2 shows the land use approximate percentage area coverage of the watershed. Agricultural land use types constituted the highest percentage within Kaduna watershed with $57.55 \%$, followed by Range-Grasses 33.2\%. Wetlands-Forested 3.93\%, Forest-Mixed 2.24\%, Residential land use $1.46 \%$, Wetlands-Mixed $0.69 \%$, Water $0.57 \%$ and Barren land use constituted only $0.38 \%$ and the lowest of all the land use types. 
Table 2. Land use land cover classification of the study area watershed

\begin{tabular}{llccc}
\hline Land use Land Cover Types & $\begin{array}{l}\text { SWAT } \\
\text { Code }\end{array}$ & $\begin{array}{c}\text { Area } \\
\text { (ha) }\end{array}$ & $\begin{array}{c}\text { Area } \\
\text { (acres) }\end{array}$ & $\begin{array}{c}\text { \% Watershed } \\
\text { Area }\end{array}$ \\
\hline Range-Grasses & RNGE & 1066467.2 & 2635293.775 & 32.73 \\
Agricultural Land-Generic & AGRL & 1848911.895 & 4568753.739 & 56.7 \\
Barren & BARR & 12070.7517 & 29827.431 & 0.61 \\
Residential & URBN & 46746.2108 & 115512.2242 & 1.78 \\
Wetlands-Mixed & WETL & 22091.7579 & 54589.8384 & 1.01 \\
Forest-Mixed & FRST & 71832.8666 & 177502.605 & 2.44 \\
Wetlands-Forested & WETF & 125877.9664 & 311050.7488 & 3.93 \\
Water & WATR & 18464.2243 & 45626.0215 & 0.81 \\
\hline
\end{tabular}

These classifications validated CILSS (2016) of West Africa landscape classification. The land-use is principally agriculture $57.55 \%$ the results corroborate Arowolo, \& Deng (2018) the authors confirmed land-use conversion to agricultural land to the detriment of grassland, forest and shrubland in the study area. Range grasses constituted 33.2\% (Abbas, Bello \& Abdullahi 2018; Arowolo, \& Deng 2018; CILSS 2016). These two land-use (Agriculture and range grasses) constituted $90.75 \%$ of the watershed land-use types. However, these two land-use types have different impacts on sediment yield generation. Land surface change plays an important role in runoff (Dong et al., 2012; Jiang et al., 2015). Increase or decrease in surface runoff will have an impact on sediment yield generation.

The soil map of the study area watershed was reclassified by the SWAT model into eleven (11) soil types (Figure 4B). The dominant soil in the watershed is sandy soil classes it consists of 98\% (Sandy-Loam and Sandy_Clay_Loam): Sandy-Loam has a total watershed land area of $51.97 \%$, followed by Sandy_Clay_Loam 46.38\%, Loam 1.64\% and Loamy_Sand 0.01\%. (Figure 4D). Table 3 shows the soil types approximate percentage area coverage for the watershed.

Table Error! No text of specified style in document.. Kaduna watershed soil classification

\begin{tabular}{llccc}
\hline Soil Class & SWAT Code & $\begin{array}{c}\text { Area } \\
\text { (ha) }\end{array}$ & $\begin{array}{c}\text { Area } \\
\text { (acres] }\end{array}$ & $\begin{array}{c}\text { \%Watershed } \\
\text { Area }\end{array}$ \\
\hline SANDY_LOAM & Lf42-1a-1470 & 321040.1472 & 793306.2557 & 9.99 \\
SANDY_LOAM & Lf49-1a-1476 & 1345603.031 & 3325052.369 & 41.89 \\
SANDY_LOAM & Lf41-1-2a-1468 & 2984.3024 & 7374.3605 & 0.09 \\
SANDY_CLAY_LOAM & Lg26-2a-1511 & 607316.4238 & 1500709.249 & 18.91 \\
SANDY_CLAY_LOAM & Lf8-1493 & 808879.9539 & 1998782.81 & 25.18 \\
LOAM & I-60 & 25565.4848 & 63173.5913 & 0.8 \\
LOAM & I-c-99 & 18572.6467 & 45893.9387 & 0.58 \\
SANDY_CLAY_LOAM & Af12-2b-1020 & 46821.4064 & 115698.0363 & 1.46 \\
LOAM & I-bc-1324 & 8479.9465 & 20954.3717 & 0.26 \\
LOAMY_SAND & Ao43-1b-1056 & 390.2588 & 964.349 & 0.01 \\
SANDY_CLAY_LOAM & I-Lf-1255 & 26809.2722 & 66247.0522 & 0.83 \\
\hline
\end{tabular}


Two levels slope categories were defined for the study, the first class with a lower limit of 0 and upper limit of 5 while the second class has a lower limit of 5 and upper limit of 9999 (Figure 4C). The minimum elevation of the study area is $369 \mathrm{~m}$, while the maximum elevation is $1516 \mathrm{~m}$ above sea level, mean elevation of $675.993 \mathrm{~m}$ and a standard deviation of 133.975. The percentage watershed area of slope area of between 0-5 is $94.78 \%$, while 5-9999 constituted $5.22 \%$. Percentage of watershed area elevation between $369 \mathrm{~m}$ to $500 \mathrm{~m}, 501 \mathrm{~m}$ to 999, and 1000 above is $7.27 \%, 89.35 \%$ and $3.41 \%$ respectively (Table 4 ).

Table 4. Study area watershed slope classification

\begin{tabular}{llllll}
\hline & Slope 0-5 & $\begin{array}{l}\text { Slope } \\
\mathbf{5 - 9 9 9 9}\end{array}$ & $\begin{array}{l}\text { Elevation } \\
\mathbf{3 6 9 - 5 0 0}\end{array}$ & $\begin{array}{l}\text { Elevation } \\
\mathbf{5 0 1 - 9 9 9}\end{array}$ & $\begin{array}{l}\text { Elevation } \\
\mathbf{1 0 0 0} \text { \& Above }\end{array}$ \\
\hline Area(ha) & 3044929 & 7524171 & & & \\
Area(ha) & 167534.1 & 413985.2 & & & \\
\%Watershed Area & 94.78 & 5.22 & 7.27 & 89.35 & 3.41 \\
\hline
\end{tabular}

Substantial parts of the watershed slope definition fall within 0-5, and an elevation range of 501 to 999, making it more homogeneous in terms of slope definition and elevations considering the percentage watershed area of slope 0-5 (94,78\%) and elevation 501-999 $(89.35 \%)$.

Relationship of basin area and sediment is best defined define in a region similar in landuse, runoff and geology in order to get a good result (Morris \& Fan 1997: Dunne \& Leopold 1978; Birkinshaw \& Bathurst 2006). This important information led to the examination of the watershed land-use, soil and geology of Kaduna watershed. The analysis revealed that the soil, land-use and geology of the studied watershed shows a very high percentage of homogeneity. The watershed soil types were majorly of the sandy class which constituted $98 \%$ (Sandy_Clay_Loam and Sandy_Loam), while loam constituted on 2\% (Loam and Loamy_Sand). The sandy nature of the watershed could equally contribute to the sediment yield generation (Ichim, 1990).

The geology as explained by Igwe \& Adepehin (2013) and Areola et al., (2014) the north central geology of Nigeria where Kaduna watershed is located consisted of Precambrian basement, Therefore, the geology is of the same origin and similar in nature. The watershed slope classification majorly fell within the same category i.e. between $0-5$ is $94.78 \%$, while 59999 constituted $5.22 \%$. While the elevation ranges as follows $369 \mathrm{~m}$ to $500 \mathrm{~m}, 501 \mathrm{~m}$ to $999 \mathrm{~m}$, and 1000 above is $7.27 \%, 89.35 \%$ and $3.41 \%$ respectively. The elevation majorly fell between $501 \mathrm{~m}$ and $999 \mathrm{~m}$ these categories constituted $89.35 \%$. Examination of the above results (landuse, soil geology and slope) revealed a good level of similarity in the aforementioned factors, hence, sediment yield comparison can be made between the four-sub-watersheds that constituted Kaduna watershed.

Spatial-temporal variations of sediment along selected reaches within the watershed

Spatial-temporal variation of suspended sediment concentration of the selected Rivers in Kaduna watersheds is as summarized in Table 5. 
Table 5. Spatial-temporal variation of suspended sediment concentration of Kaduna watershed (mg/l)

\begin{tabular}{lcccc}
\hline Month & Sarkinpawa & Kaduna & Dinya & Gutalu \\
\hline March & 17.5 & 14.5 & 53.5 & 13.5 \\
April & 15.5 & 13.5 & 64 & 11.5 \\
May & 42 & 76 & 58 & 52 \\
June & 116 & 136 & 178 & 125 \\
July & 283 & 268 & 368 & 386 \\
August & 1374.5 & 1366 & 1452.5 & 1196 \\
September & 590 & 515 & 350 & 370 \\
October & 405 & 500 & 255 & 340 \\
Total & 3844 & 3889 & 3781.5 & 3444 \\
\hline
\end{tabular}

The average SSC of Sarkinpawa sub-watershed increased from the lowest in March (17.5 $\mathrm{mg} / \mathrm{l})$ to the highest in August (1374.5 mg/l) and declined in the month of October to $405 \mathrm{mg} / \mathrm{l}$, having average total SCC of $3844 \mathrm{mg} / \mathrm{l}$ for the eight-month period. Kaduna sub-watershed increased from the lowest in March $(14.5 \mathrm{mg} / \mathrm{l})$ to the highest in August $(1366 \mathrm{mg} / \mathrm{l})$ and declined in the month of October to $500 \mathrm{mg} / \mathrm{l}$, having a total average SCC of $3889 \mathrm{mg} / \mathrm{l}$, for the eight-month period. Dinya sub-watershed SSC increased from the lowest in March $(53.5 \mathrm{mg} / \mathrm{l})$ to highest in August (1452.5 mg/l) and declined in the month of October to $225 \mathrm{mg} / \mathrm{l}$, having a total average of $3781.5 \mathrm{mg} / \mathrm{l}$ for the eight-month period. Gutalu sub-watershed increase from the lowest in March $(13.5 \mathrm{mg} / \mathrm{l})$ to highest in August $(1196 \mathrm{mg} / \mathrm{l})$ and declined in the month of October to $290 \mathrm{mg} / \mathrm{l}$, having average total SSC of $3444 \mathrm{mg} / \mathrm{l}$ within the eight-month period (Figures 5).

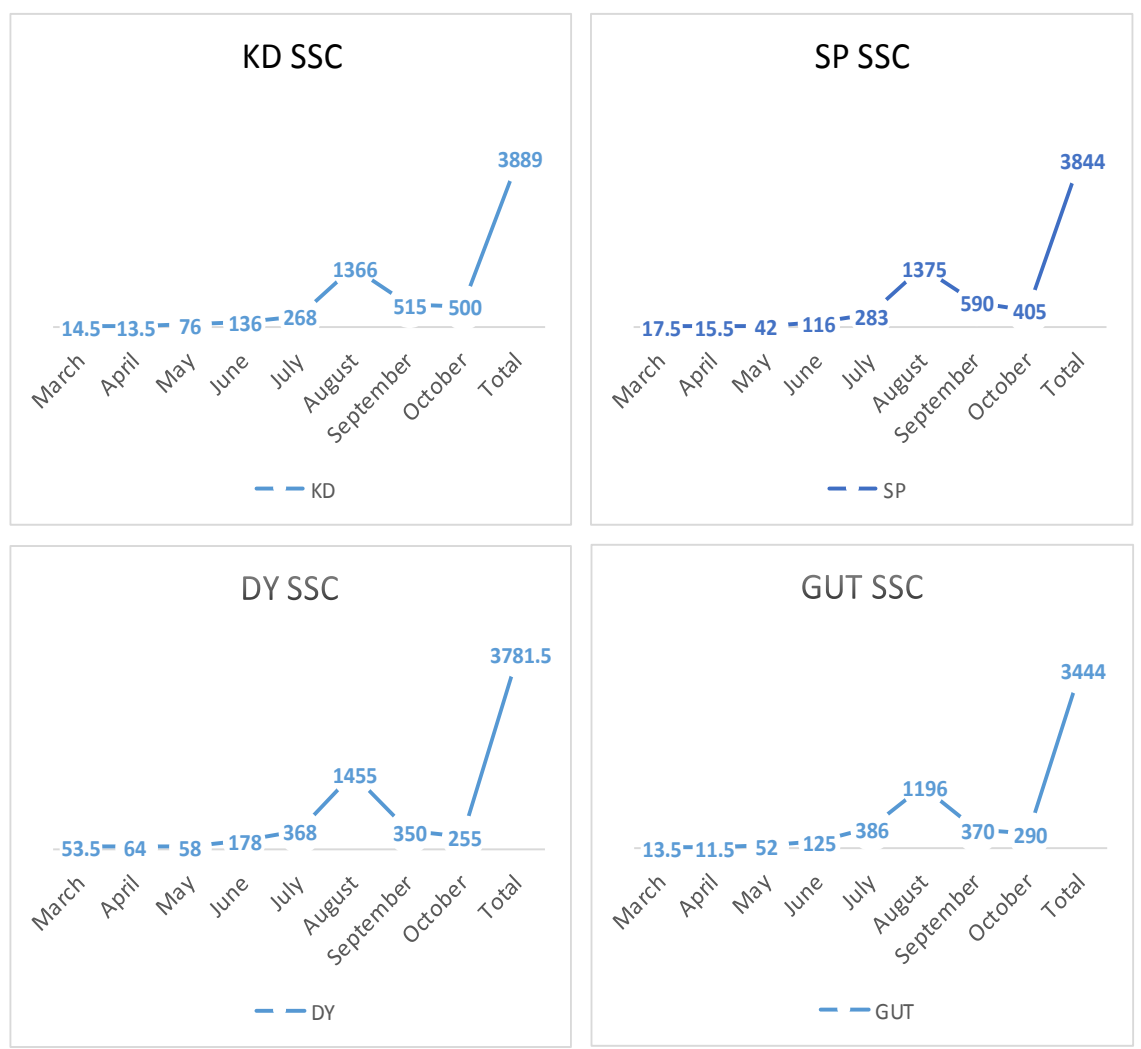

Figure 5. Monthly average of suspended sediment concentrations in the four sub-watersheds. 
The spatial variation of SSC seems not to be too pronounced among the four sampling points because the SSC in the four locations shows little difference in values. However, the temporal variation is obvious in all the sampling points. The months of July, August, September and October recorded high values of SSC with August having the highest in all the sampling, and August happened to be a month with the highest rainfall value in the watershed.

The analysis exposed the inverse relationship between the size of the sub-watersheds and suspended sediment concentration (Figure 6), Dinya sub-watershed with $1 \%$ land area contributes approximately $25 \%(3781.5 \mathrm{mg} / \mathrm{l})$ of the SSC at the entry point into the reservoir while the largest Kaduna sub-watershed with $80 \%$ land area contributes approximately $26 \%$ (3889mg/l). Sarkinpawa (11\% land area) and Gutalu (8\% land area) sub-watersheds contributes approximately 26\% (3844 mg/l) and 23\% (3444 mg/l) SSC respectively. In totality Kaduna basin with $80 \%$ of the total land area of the watershed i.e. four times larger than the remaining three sub-watersheds area contributed only 26\% (3889 mg/l), while other smaller sub-watersheds (Sarkinpawa, Gutalu and Dinya) with total land area of $20 \%$, contributed $74 \%$ of the Kaduna watershed SSC (11.069.5 mg/l ) (Karaushev, 1977; Schumm, 1977; Oyebande, 1981).

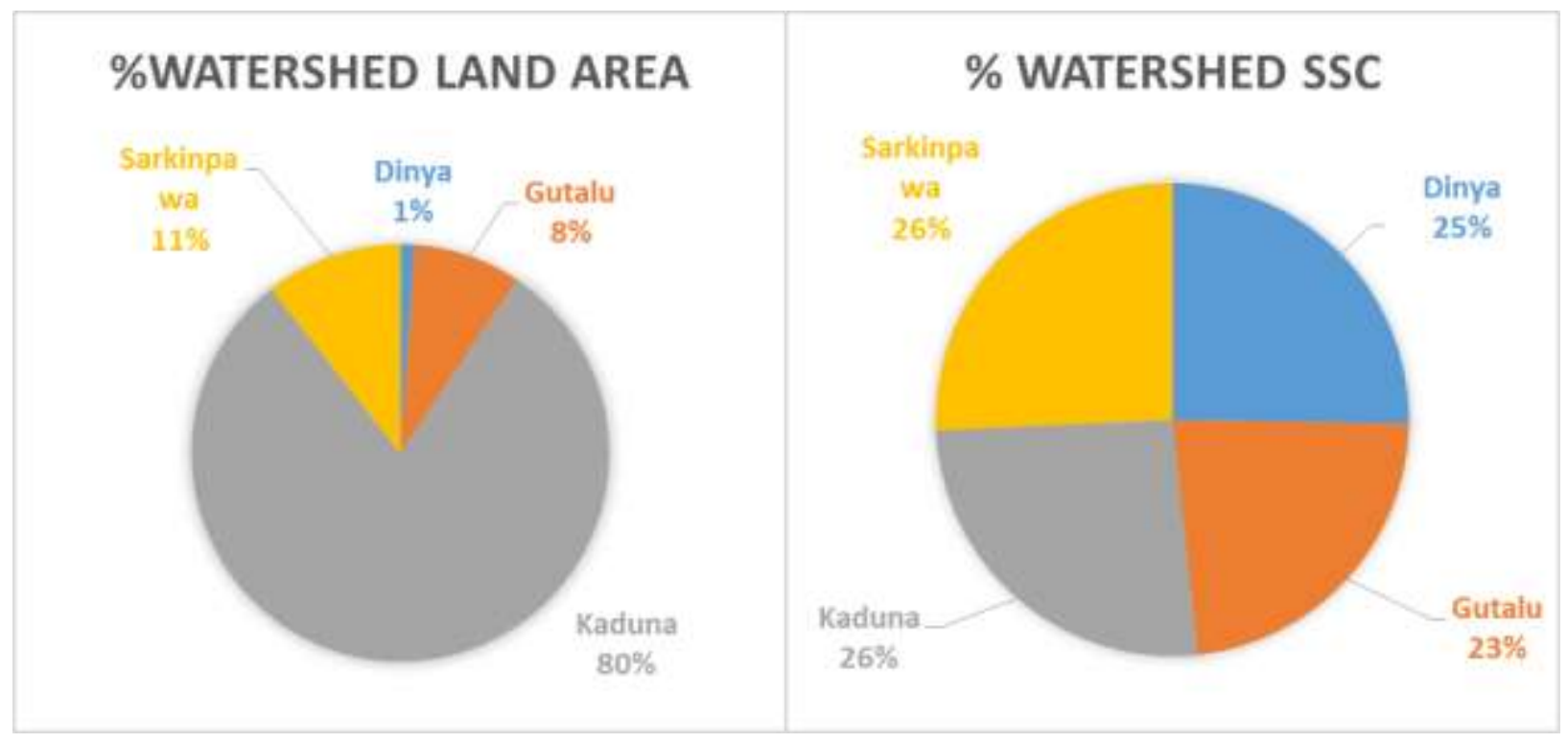

Figure 6. Percentage sub-watershed land area and percentage sub-watershed reaches SSC

The analysis established Kaduna sub-watershed to be the biggest among the four and ordinarily, it is expected to have the highest sediment yield contribution to Shiroro dam. However, reverse is the case, sediment yield in Kaduna watershed decrease with increase basin land area (Griffiths et al., 2006; Oyebande, 1981). The analysis indicated the inverse relationship between size of the sub-watersheds and suspended sediment concentration. These figures corroborate Adediji \& Fashae, (2014) findings on urban river Awba catchment Ibadan, that revealed variation in suspended sediment yield concentration that varied between $636 \mathrm{mg} / \mathrm{l}$ in May and $3641.5 \mathrm{mg} / \mathrm{l}$ in September.

Studies have attributed inverse relationship to many factors such as steeper slopes and stream gradients in smaller watershed compare to larger basins (Umit, 2015), topography (Milliman \& Syvitski, 1992), sediment sources like hillslope erosion and bank erosion sources can lead to increase or decrease in sediment yield (Birkinshaw \& Bathurst, 2006). While, Ichim, 
(1990), attributes inverse relationship in small basins to relief, higher precipitation and higher erodible rock as factor that can lead to high sediment delivery ratio. These factors by Ichim (1990) better explain the reasons behind the inverse relationship in the smaller Kaduna subwatersheds, because the smaller sub-watersheds were located in the southern part of the watershed and received more rainfalls than the northern parts (Mohammed, 2014; Areola et al., 2014), with easily erodible sandy soil.

\section{Rainfall and Suspended Sediment Concentration}

Suspended sediment concentration of the study area followed the rainfall pattern of the area, an indication that rainfall is a major determinant of sediment concentration within the watershed (Adediji \& Fashae 2014; Roudier et al., 2014). The SSC increased in values as rainfall increase progressively from the month of April and reached its peak in August and started to decline by September (Areola et al. 2014; Mahmud et al., 2012). The SSC trend in the watershed follows the same pattern with the rainfall, having the highest values in the month of August in the watershed under study (Table 6).

Table 6. Rainfall and sediment concentration pattern of the study area

\begin{tabular}{lllllll}
\hline Months & PPT Shiroro & PPT Kaduna & SP & KD & DY & GUT \\
\hline Mar & 0 & 0.055 & 17.5 & 14.5 & 53.5 & 13.5 \\
Apr & 21.6 & 32.503 & 15.5 & 13.5 & 64 & 11.5 \\
May & 152.8 & 165.905 & 42 & 76 & 58 & 52 \\
Jun & 226.85 & 275.95 & 116 & 136 & 178 & 125 \\
Jul & 352.5 & 182.436 & 283 & 268 & 368 & 386 \\
Aug & 443.0 & 290.228 & 1375 & 1366 & 1455 & 1196 \\
Sep & 289.07 & 241.53 & 590 & 515 & 350 & 370 \\
Oct & 77.9 & 77.9 & 405 & 500 & 255 & 290 \\
\hline
\end{tabular}

Suspended sediment sample analysis results and rainfall data (Table 6) were used to establish the relationship between SSC in each of the sub-watersheds (Kaduna, Sarkinpawa, Gutalu and Dinya) and rainfall. The regression analysis shows that given the percentage of the variability of the dependent variable (SSC of Kaduna, Sarkinpawa, Gutalu and Dinya) is highest in Gutalu (65\%), followed by Dinya (59\%), Sarkinpawa, (56\%), Kaduna (51\%), has explained by the in-depended variable (rainfall). The regression results for the four sub-watersheds shows a good level of linearity between rainfall and sediment concentration (Figure 7). The regression results for the four sub-watersheds shows a moderate level of linearity between rainfall and sediment concentration. These further established the importance of rainfall on the temporal variations of the study area SSC and sub-watersheds. These established existing literature on rainfall and SSC pattern in Nigeria (Adediji \& Fashae 2014; Adeola et al., 2014; Roudier, Ducharne \& Feyen, 2014). 


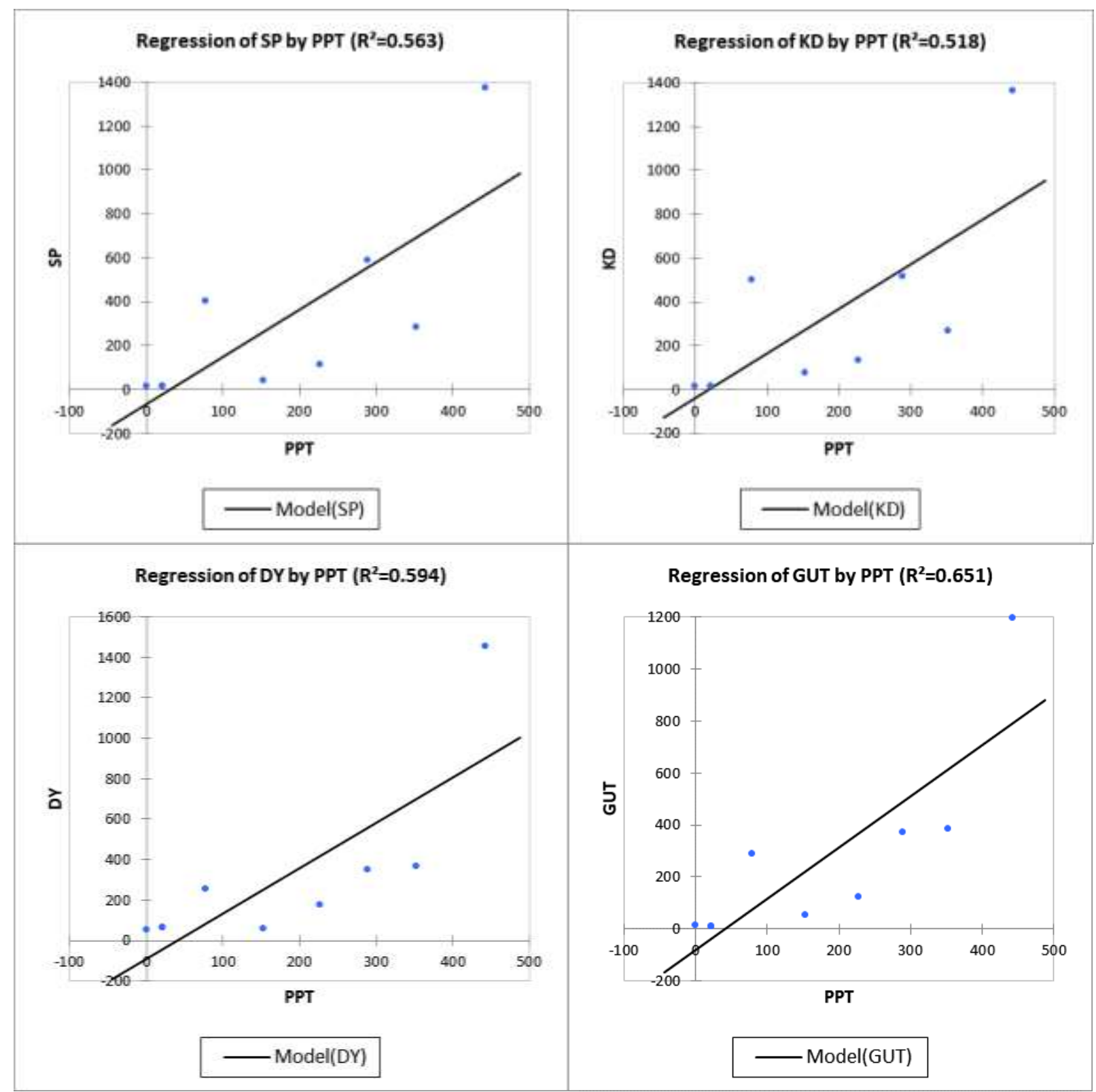

Figure 7. Regression analysis of rainfall and sub-watersheds suspended sediment concentration

Spatial-temporal variation of turbidity along selected rivers within the watershed

Variation of watershed reaches turbidity of the four sub-watersheds that constituted Kaduna watershed (Table 7). 
Table 7: Spatial-Temporal Variation of Kaduna Watershed Reaches Turbidity

\begin{tabular}{lllll}
\hline Month & SP(Turb) & KD(Turb) & DY(Turb) & GUT(Turb) \\
\hline March & 19.5 & 20 & 22.5 & 10.5 \\
April & 18 & 19 & 29 & 10 \\
May & 18 & 25.5 & 35 & 14.5 \\
June & 92.5 & 92.5 & 95 & 120 \\
July & 137.5 & 117.5 & 129 & 125 \\
August & 150 & 132.5 & 130 & 132.5 \\
September & 92.5 & 95 & 90 & 115 \\
October & 50 & 39 & 46.5 & 42.5 \\
Total & 578 & 541 & 577 & 570 \\
\hline
\end{tabular}

The average turbidity of Sarkinpawa reach increased from the lowest in March (19.5 NTU) to highest in August (150 NTU) and declined to 50 NTU in October, the basin has a total average turbidity of 578 NTU for the eight-month period, Kaduna reach increased from the lowest in March (20 NTU) to highest in August (132.5 NTU) and declined in the month of October to 39 NTU, with average turbidity of 541 NTU. Dinya reach increased from the lowest in March (22.5 NTU) to highest in August (130 NTU) and declined in the month of October to 46.5 NTU, the basin has total average turbidity of 577 NTU. Gutalu reach increased from the lowest in March (10.5 NTU) to highest in August (132.5 NTU) and declined in the month of October to $42.5 \mathrm{NTU}$, the basin has total average turbidity of $570 \mathrm{NTU}$ for the eight-month period (Figure 8).

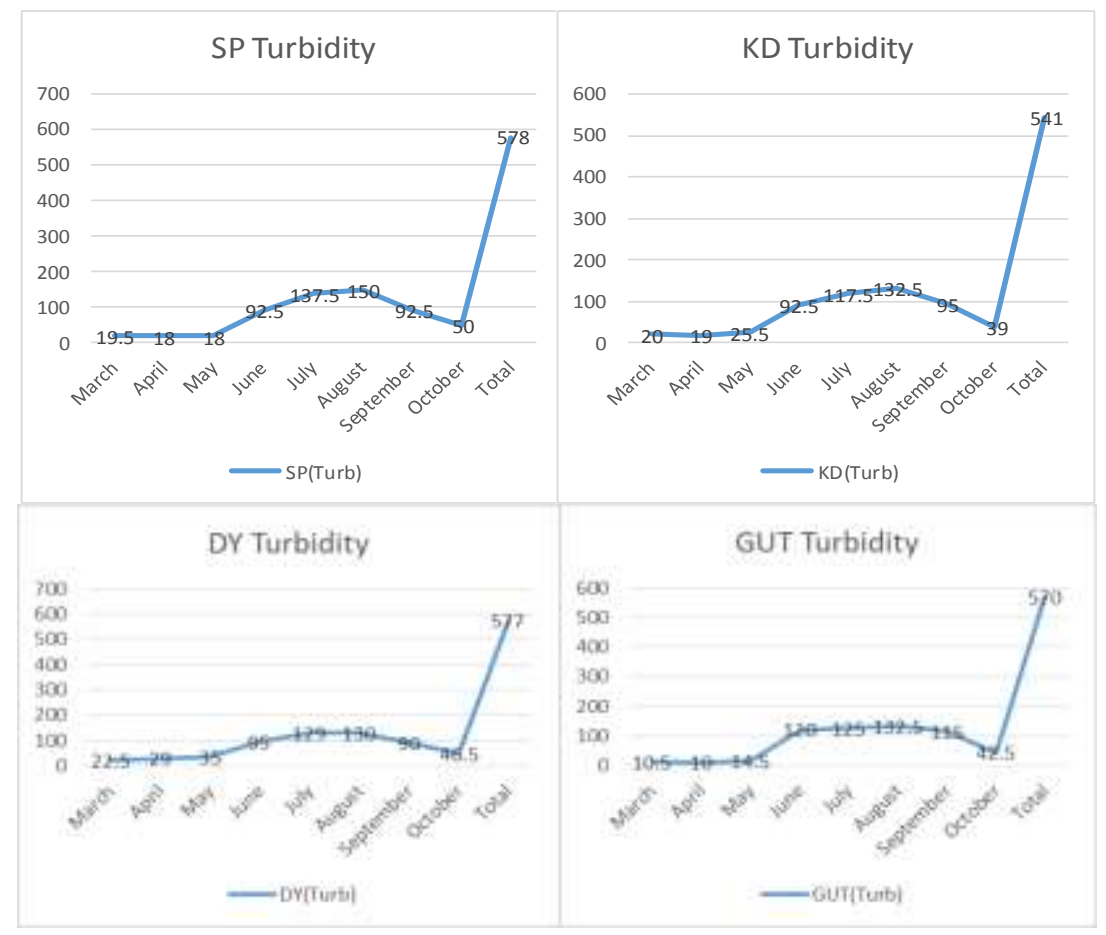

Figure 8. Turbidity variation of the four sub-watershed reaches 
The turbidity analysis also followed the same pattern with rainfall and SSC, having the highest values in the month of August (Adeogun et al., 2014). The temporal variation is more pronounced than the spatial variation. Turbidity increase progressively as the rainfall increases, these further confirmed rainfall as the major factor of erosion in the watershed.

\section{Relationship between suspended sediment concentration and turbidity}

Sediment sample analysis results of SSC (Table 5) and turbidity (Table 7) of the four subwatershed reaches: (Sarkinpawa (SP), Kaduna (KD), Dinya (DY) and Gutalu (GUT)) were used to establish the relationship between SSC and turbidity. The regression analysis shows that given the percentage of the variability of the dependent variable (turbidity) is highest explained by sediment (independent) variable in Sarkinpawa, with $\mathrm{r}^{2}$ of $56 \%$, followed by Dinya (49\%), Kaduna (46\%), and Gutalu (43\%). The regression results for the four sub-watersheds shows a moderate level of linearity between sediment concentration and turbidity (Figure 9).

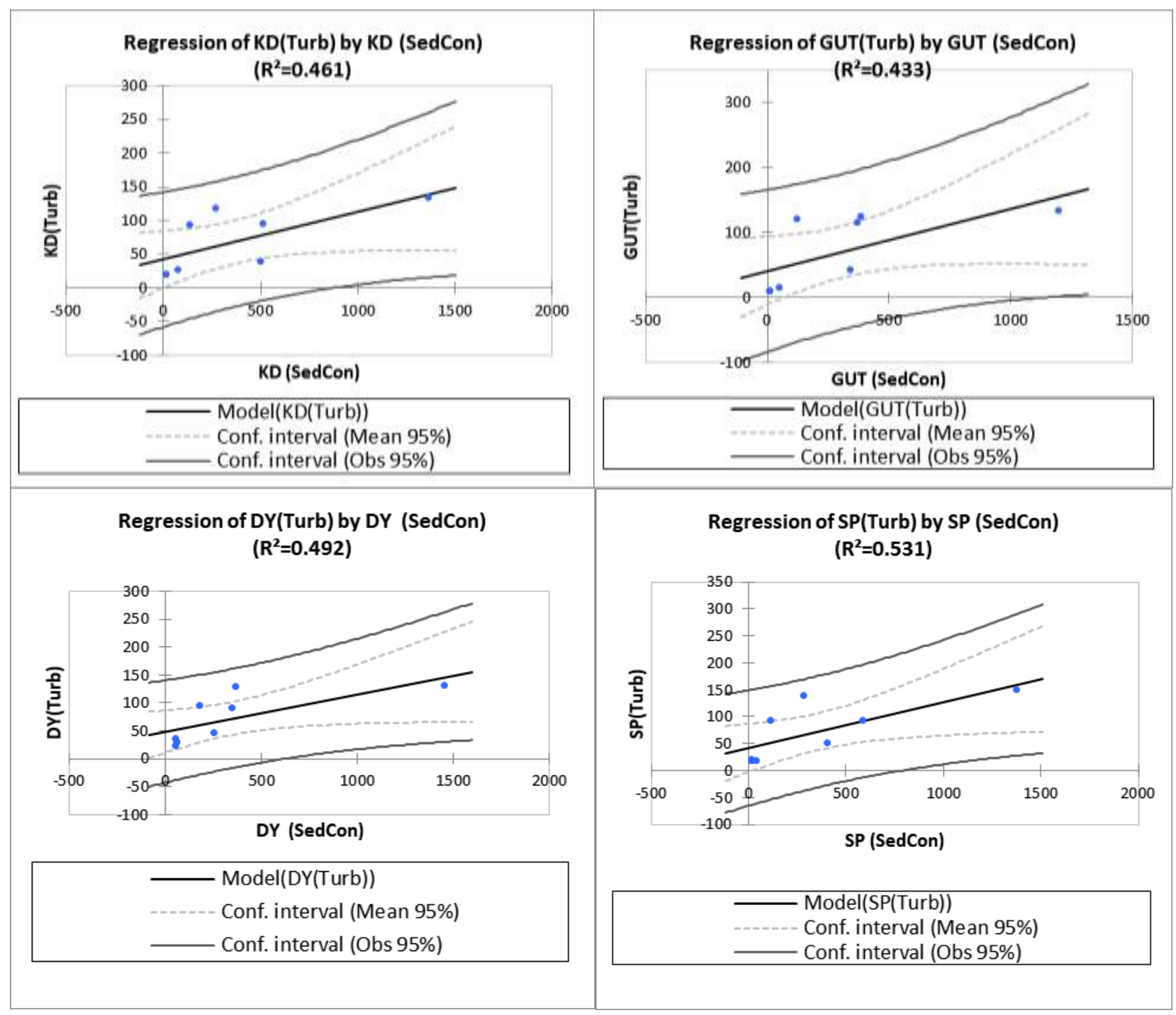

Figure 9. Relationship between SSC and Turbidity 
Spatial-temporal variation of reaches turbidity in the four sub-watersheds that constituted Kaduna watershed show the highest turbidity in reach Sarkinpawa (578 NTU) followed by Dinya (577 NTU), Gutalu (570 NTU) and Kaduna (541 NTU) in that order. These results reflect the suspended sediment concentrations of the reaches. The regression analysis shows a moderate level of correlations between suspended sediment and turbidity in the study area. These confirmed that the smaller sub-watersheds yielded more sediment into the reservoir than the giant Kaduna sub-watershed. More also, the turbidity results based on the regression results are pointing to other factors such as industrial and wastewater pollution that may be partially responsible for the reaches turbidity outside sediment yield.

\section{Conclusion}

The study established that small watershed in the study area generates more SSC than the larger one. Therefore, the outcome of the study could guide Shiroro dam management and other authority concern on the best management practice that is more suitable for the three smaller sub-watersheds of Sarkinpawa, Gutalu and Dinya, for sustainable watershed and dam management in order to curb soil erosion, sediment yield and reduce sediment load into the reservoir. The study also revealed the SSC peak period to be between the months of July to October following the rainfall trend of the study area, this foreknowledge will give room for adequate provision ahead of time that will curb the impacts of sediment influx in the reservoir. This information generally will provide good information at national level and aid government policy decision. More also, details study of the entire Kaduna watersheds is highly recommended to have a better understanding of the factors responsible for high sediment generation in the subwatersheds of Dinya, Gutalu and Sarkinpawa.

\section{Acknowledgement}

The authors acknowledge the help rendered by the management of Shiroro Hydro-Power Station and Mr Baba Bulus Musa, Department of Water Resources, Aquaculture and Fisheries Technology, The Federal University of Technology Minna, Niger State, Nigeria.

\section{References}

Abbas, I. I., Bello, O. M. \& Abdullahi, H. (2018). Mapping and analyzing the land use-land cover of Nigeria between 2001 and 2009. MOJ Eco Environ Sci., 3(3), 197-205.

Adediji, A \& Fashae, O. A. (2014). Sediment dynamics in a small, 2nd order urban river Awba catchment, Ibadan, Nigeria. Journal of Environmental Geography, 7(1-2), 23-28. DOI: 10.2478/jengeo-2014-0003 ISSN: 2060-467X.

Adeogun A. G. Sule, B. F. \& Salami, A. W. (2018). Cost-effectiveness of sediment management strategies for mitigation of sedimentation at Jebba hydropower reservoir, Nigeria. Journal of King Saud University-Engineering Sciences, 30, pp 141-149.

Adeogun, A. G., Sule, B. F., Bakare, U.T., \& Salami, A.W. (2014). Temporal Variations of Suspended Sediments along Selected Tributaries into Jebba Lake. USEP: Journal of 
Research Information in Civil Engineering, 11(2).

APHA, (1992). Standard Methods for the Examination of Water and Wastewater. 18th ed. American Public Health Association, Washington, DC.

Areola O., Ahmed, K., Iruegbu, O., Adeleke, O., Leong, G. (2014). Comprehensive Certificate Geography for Senior Secondary Schools, Revised edition. Published by University press PLC.

Arowolo, A.O. \& Deng, X. (2018). Land use/land cover change and statistical modelling of cultivated land change drivers in Nigeria. Reg Environ Change 18: 247. https://doi.org/10.1007/s10113-017-1186-5

Bartram, J. and Ballance, R. (1996). Water Quality Monitoring A Practical Guide to the Design and Implementation of Freshwater Quality Studies and Monitoring Programmes Published on Behalf of United Nations Environment Programme and the World Health Organization (C) 1996 UNEP/WHO ISBN 0419223207 (Hbk) 0419217304 (Pbk).

Bello, O. B., Ganiyu, O. T, Wahab, M. K. A., Afolabi, M. S., Oluleye, F. S. A., Mahmud, J., Azeez M. A. \& Abdulmaliq, S. Y. (2012). Evidence of Climate Change Impacts on Agriculture and Food Security in Nigeria International Journal of Agriculture and Forestry, 2(2), 49-55.

Birkinshaw, S. J, and Bathurst, J. C. (2006). Model study of the relationship between sediment yield and river basin area. Earth Surface Processes and Landforms, 31(6), 750-761.

CILSS, (2016). Landscapes of West Africa. A Window on a Changing World. U.S. Geological Survey EROS, 47914 252nd St, Garretson, SD 57030, United States.

Dedkov, A. (2004). The Relationship between Sediment Yield and Drainage Basin Area. Sediment Transfer through the Fluvial System (Proceedings of a symposium held in Moscow. August 2004). IAHS Publ. 288. 2004.

Dunne, T, \& Leopold L. B. (1978). Water in Environmental Planning. Freeman, San Francisco, 818 pp.301-306.

Dong, C.-D.; Chen, C.-F. \& Chen, C.-W (2012). Determination of Polycyclic Aromatic Hydrocarbons in Industrial Harbor Sediments by GC-MS. Int. J. Environ. Res. Public Health, 9(6), 2175-2188. https://doi.org/10.3390/ijerph9062175

Griffiths, P.G., Hereford, R. \& Webb, R. H. (2006), Sediment yield and runoff frequency of small drainage basins in the Mojave Desert. U.S.A. Geomorphology, 74, 232-244.

Igwe, O and Adepehin, J. E. (2013). Alternative Approach to Clay Stabilization Using Granite and Dolerite Dusts Geotechnical and Geological Engineering, An International Journal ISSN 0960-3182, Geotech Geol Eng. DOI 10.1007/s10706-017-0200-5

Ichim, I. (1990). The relationship between sediment delivery ratio and stream order: a Romanian case study Erosion, transport and deposition Processes (proceedings of the Jerusalem Workshop, March -April 1987) IAHS Publ no. 189, Pp79-86.

Jiang, Y, Liu, C, Li, X, Liu, L \& Wang, H. (2015). Rainfall-runoff modeling, parameter estimation and sensitivity analysis in a semiarid catchment. Environmental Modelling \& Software, 67, 72-88.

Karaushev, A. V. (ed.) (1977). Stok Nanosov, ego Izucheniye $i$ Geographicheskoe Rasprostranenie Sediment Yields, their Study and Geographical Distribution). Hydrometeoizdal, Leningrad, Russia (in Russian).

Morris G. L, \& Fan, J. (1997). Reservoir Sedimentation Handbook. McGraw-Hill, New York.

Mohammed, S. Y. (2014). Surface Runoff Responses to Rainfall Variability over the Bida Basin, Nigeria. Journal of Environment and Earth Science, 4(3), 2014. 
Milliman, J. D.\&. Syvitski, J. P. M. (1992). Geomorphic tectonic control of sediment discharge to the ocean: the importance of small mountainous rivers. J. Geol. 100, 525-544

Oyebande, L. (1981). Sediment transport and river basin management in Nigeria. In R., Lai \& E.W., Russell (eds.) Tropical Agricultural Hydrology, 201-225. John Wiley, Chichester, UK.

Owens \& Slaymaker, (1992). Late Holocene sediment yields in small alpine and subalpine drainage basins, British Columbia Erosion, Debris flows and Environment in Mountain Regions (Proceedings of the Chengdu Symposium, July 1992). IAHS Publ. no. 209, 1992.

Peyrillé, P., Lafore, J. P., \& Redelsperger J. L. (2007). An idealized two-dimensional framework to study the West African Monsoon. Part I: Validation and Key Controlling Factors. Journal of the atmospheric sciences, Vol 64. Pp 2765- 2782.

Roudier, P, Ducharne, A \& Feyen, L. (2014) Climate change impacts on runoff in West Africa: A review. Hydrol. Earth Syst. Sci., 18, 2789-2801.

Romero Díaz, M. A., Cabezas, F. \& López Bermúdez, F. (1992). Erosion and fluvial sedimentation the River Segura Basin Spain. Catena, 19, 379-395.

Singhal, H. S. S, Joshi, G.C. \& Verma, R.S. (1981). Sediment Sampling in Rivers and Canals Erosion and Sediment Transport Measurement, Proceedings of the Florence Symposium, June (1981). IAHS Publ. no. 133.

Schumm, S. A. (1977). The Fluvial System. John Wiley and Sons, New York, USA.

Summerfield, M. A. \& Hulton, N. J. (1994). Natural controls of fluvial denudation rates in major world drainage basins. J. Geophys. Res., 99, 563-582.

Thorncroft, C. D. Nguyen, H. Zhangb, C \& Peyrille, P. (2011). Annual cycle of the West African monsoon: regional circulations and associated water vapour transport. Quarterly Journal of the Royal Meteorological Society, 137, 129-147.

Toriman, M. E., Mazlin Bin Mokhtar, Othman Karim, M. Barzani Gasim and Raihan Taha (2009). Short-term sediment yields from small catchment of Sungai Anak Bangi Selangor. Bulletin of the Geological Society of Malaysia, 55, 55-59.

Toriman, M. E., Muhamad B. G, Zulkifli Y., Ismail S., Sharifah Mastura, S.A., Pauzi A., Mokhtar J., Nor Azlina Abdul Aziz, Kamarudin, M. K. A., Othman J., Othman K., Juahir, H., and Jamil, N.R. (2012). Use of 137 CS activity to investigate sediment movement and transport modeling in river coastal environment. American Journal of Environmental Science, 8(4), 417-423.

USDH-2A, (2013). USDH-2A suspended sediment sampler manual, Carnet Technology, USA.

Wasson, R. J. (1994). Annual and decadal variation of sediment yield in Australia and some global comparison. Variability in Stream and Sediment Transport, Proceeding of the Canberra Symposium, December 1994) IAHS Publ. no. 224.

Walling, D.E. (1994). Measuring sediment yield from river basins. In Lal, R. (ed.), Soil Erosion Research Methods. Soil and Water Conservation Society, Ankeny, IA.

Williams J. R. (1975). Sediment-yield prediction with universal equation using runoff energy factor. In Present and prospective technology for predicting sediment yield and sources. ARS.S-40, US Gov. Print. Office, Washington, DC. 244-252.

Zhen-Gang Ji (2017). Hydrodynamics and water quality, modeling rivers, lakes and estuaries. NJ, USA: John Wiley and Sons Inc. 